\title{
Application of cyclodextrins in antibody microparticles: potentials for antibody protection in spray drying
}

\section{Vahid Ramezani, Alireza Vatanara, Mohammad Seyedabadi, Mohsen Nabi Meybodi \& Hamed Fanaei}

To cite this article: Vahid Ramezani, Alireza Vatanara, Mohammad Seyedabadi, Mohsen Nabi Meybodi \& Hamed Fanaei (2017): Application of cyclodextrins in antibody microparticles: potentials for antibody protection in spray drying, Drug Development and Industrial Pharmacy, DOI: 10.1080/03639045.2017.1293679

To link to this article: http://dx.doi.org/10.1080/03639045.2017.1293679

Accepted author version posted online: 09

Feb 2017.

Submit your article to this journal ${ }^{\top}$

View related articles ๘

View Crossmark data $₫$ 
Application of cyclodextrins in antibody microparticles: potentials for antibody protection in spray drying

Vahid Ramezani ${ }^{\mathrm{a}}$, AlirezaVatanara ${ }^{\mathrm{b} *}$, Mohammad Seyedabadi ${ }^{\mathrm{C}}$, Mohsen Nabi Meybodi ${ }^{\mathrm{a}}$, Hamed Fanaei ${ }^{\mathrm{d}}$

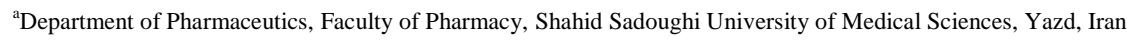

${ }^{\mathrm{b}}$ Department of Pharmaceutics, Faculty of Pharmacy, Tehran University of Medical Sciences, Tehran, Iran

${ }^{\mathrm{C}}$ Department of Pharmacology, School of Medicine, Bushehr University of Medical Sciences, Bushehr, Iran

${ }^{\mathrm{d}}$ Department of Physiology, School of Medicine, Zahedan University of Medical Sciences, Zahedan, Iran

*Corresponding author:

Corresponding author:

Phone: +98 216959057

Fax: +98216461178

E-mail address: vatanara@tums.ac.ir 


\begin{abstract}
Objectives: Dry powder formulations are extensively used to improve the stability of antibodies. Spray drying is one of important methods for protein drying. This study investigated the effects of trehalose, hydroxypropyl beta cyclodextrin (HPBCD) and beta cyclodextrin (BCD) on the stability and particle properties of spray dried IgG.
\end{abstract}

Methods: D-optimal design was employed for experimental design as well as analysis and optimization of the variables. The size and aerodynamic behavior of particles were determined using laser light scattering and glass twin impinger, respectively. In addition, stability, ratio of beta sheets, and morphology of antibody were analyzed using size exclusion chromatography, IR spectroscopy, and electron microscopy, respectively.

Results: Particle properties and antibody stability were significantly improved in the presence of HPBCD. In addition, particle aerodynamic behavior, in terms of fine particle fraction (FPF), enhanced up to $52.23 \%$. Furthermore, antibody was better preserved not only during spray drying, but also during long term storage. In contrast, application of BCD resulted in the formation of larger particles. Although trehalose caused inappropriate aerodynamic property, it efficiently decreased antibody aggregation.

Conclusion: HPBCD is an efficient excipient for development of inhalable protein formulations. In this regard, optimal particle property and antibody stability was obtained with proper combination of cyclodextrins and simple sugars, such as trehalose.

Keywords: Antibody, Spray dry, D-optimal, Trehalose, Hydroxypropyl beta cyclodextrin, Beta cyclodextrin 


\section{Introduction}

Monoclonal antibodies (mAbs) as a fast growing category of biopharmaceuticals, play an emerging role in the management of cancer and autoimmune disorders (1). More than $30 \mathrm{mAbs}$ have already been approved for clinical use. Moreover, a broad range of therapeutic antibodies are also undergoing clinical trials (2). The majority of these formulations are administered parenterally. However, recent findings suggest pulmonary route as a potential alternative for local and/or systemic delivery of proteins/peptides (3). There are several obstacles in the formulation of inhalable proteins or peptides including intrinsic instability (4). Furthermore, efficient pulmonary delivery requires highly concentrated stable antibody in every dose (5). In this regard, aggregation and surface adsorption is commonly reported in concentrated liquid formulations (6). Therefore, dry powder formulation is suggested to enhance the stability of the product (7-8).

Spray drying is one of the promising methods in particle engineering and can produce particulate systems with size ranges between 1-5 $\mu \mathrm{m}$ suitable for inhalation (9). This method has also been frequently used for the development of peptide and protein formulations. In this process, the atomized protein solution is dried by introduction to pre-heated air. Exposure to heat is the limiting step in spray drying, because extended heating can cause degradation of the proteins (10). Therefore, a suitable design of formulation is critical to minimize thermal and mechanical stresses during processing.

Various excipients, such as polyols (mannitol, trehalose, sucrose) $(8,11-14)$ and amino acids (1516) are utilized to improve protein stability and particle properties. In this regard, cyclodextrins, as a novel class of excipients, are used to improve thermal stability, permeability and solubility. In addition, they are reported to prevent protein aggregation in various formulations (17-19). In particular, cyclodextrins more effectively improved stability in comparison to trehalose (20). 
Moreover, combination of the two excipients produced synergistic effects in the stability of freeze dried proteins (21). In this regard, statistical experimental design is implemented to obtain the appropriate ratio of different excipients.

Statistical experimental design is a very useful technique to evaluate the effect of independent variables on a specific response with minimizing the number of experiments. Specifically, simultaneous change in parameters can be analysed by modelling of the data with multiple regression method. This helps optimize the variables to obtain the best results (22-23). In particular, D-optimal method is an effective tool to study the qualitative and quantitative variables together with high efficacy. It has been shown that this method is suitable for the optimization of formulation and spray drying variables $(22,24)$.

This study evaluated the effects of different excipients, particularly cyclodextrins, on the particle properties, as well as antibody stability and characterized the optimum formulation by means of D-optimal method.

\section{Materials and methods}

\subsection{Materials}

Hydroxypropyl beta cyclodextrin (HPBCD) was obtained from Acros (Belgium), and beta cyclodextrin (BCD) was obtained from Sigma (USA). Trehalose dihydrate, potassium phosphate dibasic and disodium sulfate were purchased from Merck (Germany). Human IgG (with molecular weight of about $150 \mathrm{kDa}$ ) was purchased from Kedrion (Italy). Prior to each investigation, low molecular weight additive of antibody solution was removed by dialysis (cut off: $15 \mathrm{kDa}$ ). 


\subsection{Spray drying}

Solutions of antibody were prepared by dissolving appropriate amounts of IgG, HPBCD, BCD and trehalose which were indicated in D-optimal method in deionized water with final solid concentrations of about $1 \mathrm{mg} / \mathrm{mL}$. Spray drying was performed using a lab scale Buchi-191 spray dryer (Buchi, Switzerland) with inlet temperature of $100^{\circ} \mathrm{C}$, air flow rate of $700 \mathrm{~L} / \mathrm{h}$, liquid feed rate of $1.7 \mathrm{~mL} / \mathrm{min}$, and aspiration rate of $100 \%$.

\subsection{Laser light scattering}

Laser light scattering (Malvern Instruments, UK) was applied to determine particle size. Approximately, $10 \mathrm{mg}$ of each sample was suspended in $5 \mathrm{~mL}$ of acetonitrile and sonicated for $2 \mathrm{~min}$

(Starsonic, Italy). Particle size was then measured in obscurations between 0.15 and 0.20 , and particle size distribution was defined by $\left(d_{90 \%}-d_{10 \%}\right) / d_{50 \%}$ as span parameter.

\subsection{Scanning electron microscopy (SEM)}

The morphology of spray dried particles was evaluated by scanning electron microscopy (XL30, the Netherland). Briefly, all samples were coated with a gold layer at $25^{\circ} \mathrm{C}$, and subjected to scanning at accelerated voltage of $250 \mathrm{kV}$.

\subsection{Size exclusion chromatography}

The percentage of soluble IgG aggregations, as a critical indicator for stability (25), was determined by size exclusion chromatography (SEC). Briefly, a 300 mm TSK 3000 SWXL column (Tosoh Biosep, Germany) was used to separate monomers from aggregated antibody. The mobile phase was consisted of $0.1 \mathrm{M}$ disodium hydrogen phosphate and $0.1 \mathrm{M}$ sodium sulfate $(\mathrm{pH}=6.8)$. A Waters pump (USA) was employed to supply an isocratic mobile phase with flow rate of $0.5 \mathrm{~mL} / \mathrm{min}$, 
injection volume of $20 \mu \mathrm{L}$ and protein concentration of $2.5 \mathrm{mg} / \mathrm{mL}$. Finally, protein concentrations were determined by a UV detector (Waters, USA) at $280 \mathrm{~nm}$. All experiments were performed in triplicate.

\subsection{Fourier transformation infrared spectroscopy (FT-IR)}

Samples were prepared by mixing $2 \mathrm{mg}$ of spray dried formulations and $200 \mathrm{mg} \mathrm{KBr}$. The mixture was then compressed to produce a clear tablet. Infrared spectrums were then recorded by a Nicolet Magna spectrometer, and Jasco Spectra Manager ${ }^{\circledR}$ software was used to evaluate the changes in secondary structure. In particular, second derivative spectrum of amide I region $\left(1600-1700 \mathrm{~cm}^{-1}\right)$ was used to find the peak position of deconvoluted spectra. Finally, the percentage of beta sheets, alpha helixes and turns was calculated by mixed Gaussian/Lorentzian function considering their absorption in $1640 \mathrm{~cm}^{-1}$ and $1695-1690 \mathrm{~cm}^{-1}, 1660-1650 \mathrm{~cm}^{-1}$, and $1690-1665 \mathrm{~cm}^{-1}$, respectively (26).

\subsection{In Vitro Drug Deposition}

Aerodynamic behavior of spray dried formulations was assessed using a twin stage impinge (TSI; Copley, UK) as apparatus A in European Pharmacopoeia. Briefly, HPMC capsules (size 3) were filled with $15 \mathrm{mg}$ of spray dried formulations, placed in Cyclohaler, and attached to the throat of TSI. Aerodynamic properties of powders were then tested in the air flow rate of $60 \mathrm{~L} / \mathrm{min}$ for $5 \mathrm{sec}$. Each section of TSI was washed with water and antibody content was subsequently determined using Bradford assay. 


\subsection{Experimental design}

Design expert ${ }^{\circledR}$ (trial version, 8.0.0) was applied to design the D-optimal model for the evaluation of the effects of excipients on responses, and to find the optimal formulation. The ratios of $\mathrm{BCD}$, HPBCD and trehalose to antibody ( 0 to 1 and center point of 0.5 ) were selected as independent variables. Process yield, fine particle fraction (FPF), particle size and span, antibody stability in terms of aggregation and beta sheet content were evaluated as experimental responses. The data were fitted to an appropriate model by multiple regression and the best model was selected for each response based on ANOVA (P-value<0.05) and lack of fit with $\mathrm{P}$-value<0.05. The optimum results were selected based on the curvature of response surface plots.

\section{Results}

\subsection{D-optimal model}

Aqueous solutions containing antibody and excipients were spray dried in 18 runs. As mentioned in materials and methods, several combinations of BCD, HPBCD, trehalose and antibody was formulated. Afterwards, yield, fine particle fraction (FPF), particle size distribution, stability and antibody secondary structure were determined for each formulation (Table 1). Subsequently, the effect of each independent variable as well as their interaction on each response was determined (Table 2).

\subsection{Yield}

Process yields were calculated as the amount of collected powder divided by the total solid content of feed solution (range: 15.60 to $45.16 \%$ ). Overall, the fitted model on the spray drying yield was determined by $26.98+1.38 \mathrm{~A}+2.18 \mathrm{~B}+7.51 \mathrm{C}+1.04 \mathrm{AB}+2.72 \mathrm{AC}$; where $\mathrm{A}, \mathrm{B}$, and $\mathrm{C}$ define trehalose, $\mathrm{HPBCD}$, and $\mathrm{BCD}$, respectively. This indicates that yield is best fitted to a modified two 
factor interaction $(2 \mathrm{FI})$ model (Table 2, $\mathrm{P}<0.0001)$. In fact, particles containing $\mathrm{BCD}$ or HPBCD produced higher yields. In contrast, the total yield did not seem to be dependent on the concentration of trehalose when it was used as the sole excipient. However, co-formulation of trehalose with BCD led to a significant increase in the yield. In this regard, Figure 1 demonstrates the interaction between BCD and trehalose in which maximum yield was harvested with the highest ratio of these excipients.

\subsection{Particle size and shape}

Particles produced in all formulations demonstrated unimodal and narrow size distribution in range of 1.20 to $5.34 \mu \mathrm{m}$. According to SEM picture (Fig.2) formulations containing one excipient (BCD, HPBCD, or trehalose) at the ratio of 1:1 to antibody exhibited as donut-shape after spray drying. In addition, particles containing only HPBCD showed deeper concave surface, and those containing all excipients (optimum formulation) demonstrated more spherical shape with some wrinkles on the surface.

Overall, particle size was determined by the model of; $3.16-0.71 \mathrm{~A}-0.23 \mathrm{~B}+0.67 \mathrm{C}-0.57 \mathrm{~A}^{2}-$ $0.98 \mathrm{~B}^{2}+0.99 \mathrm{C}^{2}+0.59 \mathrm{AB}$; where $\mathrm{A}, \mathrm{B}$, and $\mathrm{C}$ define trehalose, HPBCD, and $\mathrm{BCD}$, respectively. This indicates that particle size is best fitted to a modified quadratic model $(\mathrm{P}<0.0001$, Table 2$)$. In particular, there were a positive correlation between the ratio of BCD and the particle size $(\beta:+0.67$, $\mathrm{P}<0.0001)$. On the other hand, trehalose negatively influenced particle size $(\beta:-0.71, \mathrm{P}<0.0001)$. Moreover, the interaction between the ratio of trehalose and $\operatorname{HPBCD}(\mathrm{AB})$ showed that the largest particles were obtained in the curvature point with medium ratios of these components (Fig. 3).

The span parameter (size distribution) varied from 0.55 to 2.26 . Overall, size distribution was determined by $1.25-0.39 \mathrm{~A}+0.015 \mathrm{~B}+0.18 \mathrm{C}-0.38 \mathrm{~A}^{2}-0.29 \mathrm{~B}^{2}+0.66 \mathrm{C}^{2}+0.21 \mathrm{AB}+0.13 \mathrm{AC}-$ 0.12BC; where $\mathrm{A}, \mathrm{B}$, and $\mathrm{C}$ define trehalose, $\mathrm{HPBCD}$, and $\mathrm{BCD}$, respectively. This indicates that a 
modified quadratic model is best fitted to span data (Table 2; P: 0.004). Furthermore, there were an inverse relationship between the ratio of trehalose $(\beta$ : -0.015$)$ and size distribution. Whereas, increases in the levels of HPBCD ( $\beta: 0.05)$ or BCD ( $\beta: 0.8)$ significantly expanded the span parameter. Interestingly, there was a linear relationship between particle size and span (Fig.4). Furthermore, the effect of interaction between trehalose and HPBCD on span was similar to their effect on size (Fig. 5). Therefore, the narrowest size distribution was obtained when either HPBCD or trehalose was applied in maximum ratios.

\subsection{Aerodynamic properties}

In vitro deposition studies revealed that aerodynamic properties of particles were considerably affected by formulation content. Indeed, fine particle fraction (FPF) as an index of particle aerodynamic behavior varied from 7.86 to $52.23 \%$. Overall, FPF fitted model was determined by $16.49-5.58 \mathrm{~A}+7.03 \mathrm{~B}+0.33 \mathrm{C}-5.34 \mathrm{~A}^{2}+10.35 \mathrm{~B}^{2}+4.80 \mathrm{C}^{2}-6.41 \mathrm{AB}-2.61 \mathrm{AC}-4.15 \mathrm{BC}$; where $\mathrm{A}$, $\mathrm{B}$, and $\mathrm{C}$ define trehalose, $\mathrm{HPBCD}$, and $\mathrm{BCD}$, respectively. This implies that a quadratic model is the best fitted model to the FPF data (Table 2, P: 0.0004). In particular, FPF depended mainly on trehalose ( $\beta$ : -5.58, P: 0.001) and HPBCD ratios ( $\beta:$ 7.03, P: 0.0004). In other words, FPF enhanced with increase of $\mathrm{HPBCD}$ ratio but decreased with trehalose. In the meantime, $\mathrm{BCD}$ produced no significant effect on FPF.

Figure 6 shows the response surface plot for the effects of HPBCD and trehalose as well as the interaction of $\mathrm{HPBCD}$ with $\mathrm{BCD}$. The results of this experiment indicated that more inhalable particles, higher FPF, were obtained when HPBCD was used in the highest level (Fig. 6A). Moreover, BCD content negatively influenced FPF when co-formulated with HPBCD (Fig. 6B). 


\subsection{Stability}

The stability test was designed based on the guidance of FDA for biological products. The thermal stability tests included intermediate and long-term storage at $30^{\circ} \mathrm{C}$ or accelerated condition at $40^{\circ} \mathrm{C}$. The test sought to be conducted every 3 months or at shorter intervals for accelerate test (27). Antibody stability in terms of aggregation was evaluated immediately after processing and in accelerated conditions $\left(70 \%\right.$ humidity at $40^{\circ} \mathrm{C}$ ). Formulation of antibody without any excipients was susceptible to aggregation during spray drying as well as when stored at $40^{\circ} \mathrm{C}$. In contrast, all applied excipients, especially trehalose and HPBCD, inhibited aggregation with different strengths. Overall, monomer content immediately after spray drying was determined by $96.81+1.25 \mathrm{~A}+1.81 \mathrm{~B}$ $+0.98 \mathrm{C}-1.47 \mathrm{AB}$; where $\mathrm{A}, \mathrm{B}$, and $\mathrm{C}$ define trehalose, $\mathrm{HPBCD}$, and $\mathrm{BCD}$, respectively. This indicates a modified 2FI model for the protective effects of various excipients (Table 2), in which HPBCD and trehalose effectively inhibited aggregation (Fig. 7). Analyzing the adjusted model immediately after spray drying revealed that HPBCD was more effective than trehalose in the inhibition of aggregation during spray drying (coefficient of trehalose: 1.25 Vs. HPBCD: 1.81). These results were comparable to the long-term stability model. In particular, monomer content after 30 days storage at $40^{\circ} \mathrm{C}$ was determined by $94.63+1.92 \mathrm{~A}+2.36 \mathrm{~B}+1.72 \mathrm{C}-2.07 \mathrm{AB}-0.63 \mathrm{AC}-$ 0.64BC. Likewise, this value after 90 days was determined by the following model: $90.58+3.43 \mathrm{~A}+$ $3.69 \mathrm{~B}+2.98 \mathrm{C}-2.08 \mathrm{~A} \mathrm{~B}-2.43 \mathrm{AC}-1.56 \mathrm{BC}$. Table 2 indicates the protective effects of all excipients against aggregation. In addition, the protective effect of trehalose became more evident during long-term storage.

Secondary structure of protein demonstrates the folding pattern as well as stability in various conditions. In the second derivative of FTIR spectra (Fig. 8), the main band in amide I region (1640 and $1695 \mathrm{~cm}^{-1}$ ) is related to beta sheet content. As presented in Table 1, beta sheet content in various 
formulations varied between 41.1 to $66.74 \%$. Indeed, spray drying of pure protein caused major transformations in this band (Fig. 8). Whereas, the intensity of $1640 \mathrm{~cm}^{-1}$ band in formulations containing trehalose was higher than those containing no excipient or those containing HPBCD or BCD. In fact, the fitted model on beta sheet content was determined by $60.59+6.11 \mathrm{~A}+1.94 \mathrm{~B}-$ $8.09 \mathrm{~A}^{2}+4.35 \mathrm{~B}^{2}-3.57 \mathrm{AB}$; where $\mathrm{A}, \mathrm{B}$, and $\mathrm{C}$ define trehalose, $\mathrm{HPBCD}$, and $\mathrm{BCD}$, respectively. This indicates a modified quadratic model and higher beta sheet content in samples containing trehalose. HPBCD also preserved beta sheet content ( $\beta$ : 1.94), though less effectively compared to trehalose ( $\beta$ : 6.11). Surprisingly, combination of two protective agents (trehalose and HPBCD) caused a significant decrease ( $\beta$ : -3.75) in the beta sheet content (Fig, 9; P; 0.0005).

\section{Discussion}

In this study we evaluated the effects of trehalose, $\mathrm{HPBCD}$ and $\mathrm{BCD}$ on particle properties as well as stability of spray dried $\operatorname{IgG}$ formulations.

The harvesting yield is normally between $30-40 \%$ in protein dry powder preparation using bench top spray dryer (28). It mainly depends on the special cyclone design of the spry drying apparatus (28). The results of this study, however, indicates that cyclodextrins as the formulation variable can also influence the yield. As depicted in Fig. 1, increasing the ratio of BCD in formulations containing trehalose enhanced particle separation and caused entrapment in receiver. This might be due to an increase in particle size. In fact, formulations containing BCD had larger particle size. Hence, it is more likely for large particles to precipitate in reservoir and, thereby, increase the yield. 
Larger particles were obtained with BCD. In contrast, formulations containing HPBCD or trehalose produced smaller particles (Table 2). In this regard, droplet size and drying pattern are two determinant factors of particle size (29-30). In particular, Peclet number is a valuable factor to estimate the particle size, shape and surface morphology. It is calculated as: $\mathrm{Pe}_{\mathrm{i}}=\mathrm{k} / 8 \mathrm{D}_{\mathrm{i}}$; where $k$ is the evaporation rate, and $\mathrm{D}_{\mathrm{i}}$ is diffusion coefficient of solute in aqueous medium of droplets during spray drying (30). Components with lower aqueous solubility demonstrate larger Peclet number (30). In this study, particle size was positively correlated with the ratio of $B C D$, while it was inversely related to the ratio of HPBCD and trehalose. This is explained by lower aqueous solubility of BCD (31) compared with HPBCD and trehalose. Thereby, BCD results in larger Peclet number and finally increases particle size. Likewise, the inverse relationship between the ratio of HPBCD and trehalose with particle size can be due to higher aqueous solubility of HPBCD and trehalose (32) and consequently lower Peclet number. Furthermore, trehalose tends to accumulate in particle core during spray drying and reduces particle size (33-35).

Surface tension is another determinant of particle size (29). Although BCD does not influence surface tension, HPBCD decreases water surface tension, resulting in lower droplet interfacial tension (36). In this regard, interfacial tension is inversely related with particle size because of easier detachment of droplets when surface tension is reduced (37), and consequent particles will be smaller. Therefore, small particle size with HPBCD can be attributed to both reduced pecklet number and surface tension. In contrast, although higher ratio of trehalose in aqueous formulation increases the surface tension (38), we observed that co-formulation of trehalose with antibody produced particles with small size (Table 2).

Trehalose decreased particle size (Table 2) and FPF (Fig. 6).On the other hand, HPBCD decreased the particle size but enhanced the FPF. In this regard, BCD increased particle size, but did not 
significantly influenced particle aerodynamic behaviour. This implies that particle size is not the sole determinant of FPF. In fact, it is determined by both partcile size and cohesive interaction forces between the partciles (39). In this regard, trehalose increases inter molecuar attraction (40) and causes sticky agglomarates(4).This might explaine infavorable effects of trehalose on FPF inspite of size reduction. HPBCD dcreased partcile size and cohesive interaction forces. Thereby, it efficiently improved aerodynamic behaviour of the particles. Cyclodextrins have been successfully used in many studies as FPF enhancer. For instance, $\mathrm{Li}$ et al demonestrated that formulations containing dimethyl beta cyclodextrin exhibited superior powder dispersibility compared to those containing trehalose or lactose (41). Similarly, salbutamol dry powder formulation with dimethyl beta cyclodextrin showed higher FPF in comparison to formulations containing lactose (42). Moreover, budesonide formulation with cyclodextrins enhanced particle respirable fraction up to 67\% (43). Although BCD decreases cohesive interaction between the particles, it increased particle size (Table 2).This might be the reason behind the inefficiency of $\mathrm{BCD}$ to improve FPF (P: 0.786). Taken together, HPBCD with desirable effects on both particle size and cohesive interaction forces produced particles suitable for inhalation.

Antibodies are more stable in dry powder formulations than are in solutions. This is achieved by various mechanisms including glass dynamics or water substitution in solid matrix $(11,44)$. Recent studies showed that polyols improve glass dynamics and are capable of substituting water molecules (44-45). Hence, several polyols have been used for the preservation of peptides and proteins in spray drying (12). We found that trehalose, $\mathrm{HPBCD}$ and $\mathrm{BCD}$ decreased protein aggregation during spray drying and/or in long term storage. In contrast, the formulation without any excipients was dramatically susceptible to aggregation. In particular, HPBCD preserved antibody more efficiently during spray drying than did the other two excipients. This is explained by the fact that HPBCD is a 
hydrophilic cyclodextrin with surface active properties. In fact, aggregation mainly occurs in the water interface because of production of numerous droplets with large surface area during spraying (46). In addition, hydrophilic cyclodextrins can also prevent thermal-induced unfolding of proteins (47). Furthermore, cyclodextrins are cyclic oligosaccharides with lipophilic properties in the interior cavity (48). Thereby, they inhibit aggregation via covering the aromatic residues which are suggested to be the most important part of aggregation nucleus (49). Previous investigations have also showed that beta cyclodextrines (with 7-membered sugar ring molecule) are more effective than alpha (with 6-membered sugar ring molecule) or gama derivatives (with 8-membered sugar ring molecule). This is because of better docking of aromatic amino acids in the interior cavity of BCD (49). In addition, Tavornvipas et al, showed that branched beta cyclodextrins more effectively inhibit lysozyme aggregation. In this way, our results showed that HPBCD as hydrophilic branched cyclodextrin provided superior inhibitory effect against antibody aggregation than does BCD.

Although HPBCD decreased protein aggregation more effectively during spray drying, trehalose provided better protection of antibody in long term. This indicates that formation of glassy state during long term storage is more important. Thereby, excipients with positive effect on protein surface inhibit protein-protein adherence via modification of hydrogen bonds and glassy state (50$51)$.

FTIR spectroscopy is a well-known method to obtain general information about proteins secondary structure (52-54). The native structure of antibody in aqueous solutions contains about $60 \%$ betasheet. FTIR spectroscopy of antibody solution have demonstrated dramatic changes at temperatures over $90^{\circ} \mathrm{C}$ (52). Hence, spray drying at $100^{\circ} \mathrm{C}$ is expected to cause significant perturbations and unfolding in the structure. In addition to high temperature, water evaporation and solidification can also induce structural alteration. The results showed an efficient water replacement property for 
trehalose (Table 2, $\beta: 6.11$ ). This implies that it can easily form hydrogen bounds with protein surface. HPBCD also replaces water and produces hydrogen bound though is less effective than trehalose $(\beta:+1.94)$. It is reported that hydroxylalkyl cyclodextrins produce hydrogen bonds easier than their parent compound (19). In addition, we observed that incrementing the trehalose ratio has positive effect just in ratios from 0 to 0.6 , and further increase did not provide more protection. This can be due to saturation of protein surface (Fig.9).

Optimization was performed to find out the appropriate amount of each excipient and to obtain the best formulation. The optimal formulation was determined by using excipients in previously applied range to get the particle size range of $1.2-5.34 \mu \mathrm{m}$, with minimum particle size distribution and maximum value for other responses. The predicted optimal condition was composed of HPBCD, $\mathrm{BCD}$, trehalose and antibody with ratios of 1: 0.99: 0.26: 1, respectively. Table 3 demonstrates the predicted values of all responses with this formulation. There was a reasonable agreement between the predicted and experimental values in all responses.

\section{Conclusion}

The type of excipients as well as their ratios in antibody formulation influenced yield, particle size, aerodynamic behavior and antibody stability. In particular, HPBCD not only enhanced aerosol performance of the powder, but also more effectively preserved the secondary structure and inhibited aggregation during spray drying. Also, trehalose is efficient in protection of antibody against aggregation in long term storage but did not influence particle aerodynamic behavior. Furthermore, BCD enhanced spray drying yield. The optimal formulation seems to be composed of HPBCD, $\mathrm{BCD}$, trehalose and antibody with ratios of 1: 0.99: 0.26: 1, respectively. 


\section{Declaration of interest}

The authors report no conflict of interest. The authors alone are responsible for the content and writing of this paper.

\section{References}

1. Dani B, Platz R, Tzannis ST. High concentration formulation feasibility of human immunoglubulin $G$ for subcutaneous administration. J Pharm Sci. 2007 Jun;96(6):1504-17.

2. Marichal-Gallardo PA, Álvarez MM. State-of-the-art in downstream processing of monoclonal antibodies: Process trends in design and validation. Biotechnology Progress. 2012;28(4):899-916.

3. Kane C, O'Neil K, Conk M, Picha K. Inhalation delivery of protein therapeutics. Inflammation \& Allergy-Drug Targets (Formerly Current Drug Targets-Inflammation \& Allergy). 2013;12(2):81-7.

4. Schule S, Schulz-Fademrecht T, Garidel P, Bechtold-Peters K, Frieb W. Stabilization of IgG1 in spray-dried powders for inhalation. Eur J Pharm Biopharm. 2008 Aug;69(3):793-807.

5. Fahy JV, Cockcroft DW, Boulet LP, Wong HH, Deschesnes F, Davis EE, et al. Effect of aerosolized anti-IgE (E25) on airway responses to inhaled allergen in asthmatic subjects. Am J Respir Crit Care Med. 1999 Sep;160(3):1023-7.

6. Daugherty AL, Mrsny RJ. Formulation and delivery issues for monoclonal antibody therapeutics. Advanced Drug Delivery Reviews. 2006;58(5-6):686-706.

7. Ibrahim M, Verma R, Garcia-Contreras L. Inhalation drug delivery devices: technology update. Medical Devices (Auckland, NZ). 2015;8:131-9.

8. Ramezani V, Vatanara A, Najafabadi AR, Shokrgozar MA, Khabiri A, Seyedabadi M. A comparative study on the physicochemical and biological stability of IgG 1 and monoclonal antibodies during spray drying process. DARU Journal of Pharmaceutical Sciences. 2014;22(1):1.

9. Chow A, Tong $H$, Chattopadhyay $P$, Shekunov B. Particle Engineering for Pulmonary Drug Delivery. Pharmaceutical Research. 2007;24(3):411-37.

10. Wang W, Singh S, Zeng DL, King K, Nema S. Antibody structure, instability, and formulation. Journal of pharmaceutical sciences. 2007;96(1):1-26.

11. Chang LL, Shepherd D, Sun J, Ouellette D, Grant KL, Tang XC, et al. Mechanism of protein stabilization by sugars during freeze-drying and storage: native structure preservation, specific interaction, and/or immobilization in a glassy matrix? J Pharm Sci. 2005 Jul;94(7):1427-44.

12. Andya JD, Maa YF, Costantino HR, Nguyen PA, Dasovich N, Sweeney TD, et al. The effect of formulation excipients on protein stability and aerosol performance of spray-dried powders of a recombinant humanized anti-IgE monoclonal antibody. Pharm Res. 1999 Mar;16(3):350-8.

13. Costantino HR, Andya JD, Nguyen PA, Dasovich N, Sweeney TD, Shire SJ, et al. Effect of mannitol crystallization on the stability and aerosol performance of a spray-dried pharmaceutical protein, recombinant humanized anti-IgE monoclonal antibody. J Pharm Sci. 1998 Nov;87(11):140611.

14. Ramezani V, Vatanara A, Rouholamini Najafabadi A, Gilani K, Nabi-Meybodi M. Screening and evaluation of variables in the formation of antibody particles by spray drying. Powder Technology. 2013;233(0):341-6. 
15. Chen B, Bautista R, Yu K, Zapata GA, Mulkerrin MG, Chamow SM. Influence of histidine on the stability and physical properties of a fully human antibody in aqueous and solid forms. Pharm Res. 2003 Dec;20(12):1952-60.

16. Faghihi H, Vatanara A, Najafabadi AR, Ramezani V, Gilani K. The use of amino acids to prepare physically and conformationally stable spray-dried IgG with enhanced aerosol performance. International journal of pharmaceutics. 2014;466(1):163-71.

17. Fernández $M$, Villalonga $M L$, Fragoso $A$, Cao $R$, Villalonga R. Effect of $\beta$-cyclodextrinpolysucrose polymer on the stability properties of soluble trypsin. Enzyme and Microbial Technology. [doi: 10.1016/j.enzmictec.2003.09.003]. 2004;34(1):78-82.

18. Castellanos IJ, Flores G, Griebenow K. Effect of cyclodextrins on alpha-chymotrypsin stability and loading in PLGA microspheres upon S/O/W encapsulation. J Pharm Sci. 2006 Apr;95(4):849-58.

19. Serno T, Geidobler R, Winter G. Protein stabilization by cyclodextrins in the liquid and dried state. Advanced Drug Delivery Reviews. [doi: 10.1016/j.addr.2011.08.003]. 2011;63(13):1086-106.

20. Iwai J, Ogawa N, Nagase H, Endo T, Loftsson T, Ueda H. Effects of various cyclodextrins on the stability of freeze\&\#x2010;dried lactate dehydrogenase. Journal of Pharmaceutical Sciences. [doi: 10.1002/jps.20847].96(11):3140-3.

21. Santagapita PR, Brizuela LG, Mazzobre MF, Ramírez HL, Corti HR, Santana RV, et al. $\beta$ Cyclodextrin modifications as related to enzyme stability in dehydrated systems: Supramolecular transitions and molecular interactions. Carbohydrate Polymers. 2011;83(1):203-9.

22. Mohajel N, Najafabadi AR, Azadmanesh K, Vatanara A, Moazeni E, Rahimi A, et al. Optimization of a spray drying process to prepare dry powder microparticles containing plasmid nanocomplex. Int J Pharm. 2012 Feb 28;423(2):577-85.

23. Nahata T, Saini TR. D-optimal designing and optimization of long acting microsphere-based injectable formulation of aripiprazole. Drug Dev Ind Pharm. 2008 Jul;34(7):668-75.

24. Kamairudin N, Gani SS, Masoumi HR, Hashim P. Optimization of natural lipstick formulation based on pitaya (Hylocereus polyrhizus) seed oil using D-optimal mixture experimental design. Molecules. 2014 Oct 16;19(10):16672-83.

25. Mahler HC, Friess W, Grauschopf U, Kiese S. Protein aggregation: Pathways, induction factors and analysis. Journal of Pharmaceutical Sciences. 2009;98(9):2909-34.

26. Kong J, Yu S. Fourier transform infrared spectroscopic analysis of protein secondary structures. Acta Biochim Biophys Sin (Shanghai). 2007 Aug;39(8):549-59.

27. Food, Administration D. Guidance for industry Q1A (R2) stability testing of new drug substances and products. Food and Drug Administration Rockville, MD. 2003.

28. Maa YF, Nguyen PA, Sit K, Hsu CC. Spray-drying performance of a bench-top spray dryer for protein aerosol powder preparation. Biotechnology and bioengineering. 1998;60(3):301-9.

29. Elversson J, Millqvist-Fureby A, Alderborn G, Elofsson U. Droplet and particle size relationship and shell thickness of inhalable lactose particles during spray drying. Journal of Pharmaceutical Sciences. 2003;92(4):900-10.

30. Vehring R. Pharmaceutical particle engineering via spray drying. Pharmaceutical Research. 2008;25(5):999-1022.

31. Chatjigakis AK, Donze C, Coleman AW, Cardot P. Solubility behavior of .beta.-cyclodextrin in water/cosolvent mixtures. Analytical Chemistry. [doi: 10.1021/ac00038a022]. 1992 1992/07/01;64(14):1632-4. 
32. Häusler O, Müller-Goymann CC. Properties and Structure of Aqueous Solutions of Hydroxypropyl-beta-Cyclodextrin. Starch-Stärke. 1993;45(5):183-7.

33. Feng AL, Boraey MA, Gwin MA, Finlay PR, Kuehl PJ, Vehring R. Mechanistic models facilitate efficient development of leucine containing microparticles for pulmonary drug delivery. International Journal of Pharmaceutics. [doi: 10.1016/j.ijpharm.2011.02.049]. 2011;409(1-2):15663.

34. Adler $M$, Unger $M$, Lee $G$. Surface composition of spray-dried particles of bovine serum albumin/trehalose/surfactant. Pharmaceutical Research. 2000;17(7):863-70.

35. Adler M, Lee G. Stability and surface activity of lactate dehydrogenase in spray-dried trehalose. J Pharm Sci. 1999 Feb;88(2):199-208.

36. Ishiguro T, Morishita E, lohara D, Hirayama F, Wada K, Motoyama K, et al. Some pharmaceutical and inclusion properties of 2-hydroxybutyl-beta-cyclodextrin derivative. Int J Pharm. 2011 Oct 31;419(1-2):161-9.

37. Iskandar F, Gradon L, Okuyama K. Control of the morphology of nanostructured particles prepared by the spray drying of a nanoparticle sol. Journal of Colloid and Interface Science. [doi: 10.1016/S0021-9797(03)00519-8]. 2003;265(2):296-303.

38. Kaushik JK, Bhat R. Why is trehalose an exceptional protein stabilizer? An analysis of the thermal stability of proteins in the presence of the compatible osmolyte trehalose. Journal of Biological Chemistry. 2003;278(29):26458-65.

39. Maa Y-F, Nguyen P-A, Sweeney T, Shire SJ, Hsu CC. Protein inhalation powders: spray drying vs spray freeze drying. Pharmaceutical Research. 1999;16(2):249-54.

40. Hooton JC, Jones MD, Price R. Predicting the behavior of novel sugar carriers for dry powder inhaler formulations via the use of a cohesive-adhesive force balance approach. J Pharm Sci. 2006 Jun;95(6):1288-97.

41. Li HY, Seville PC, Williamson IJ, Birchall JC. The use of absorption enhancers to enhance the dispersibility of spray-dried powders for pulmonary gene therapy. The Journal of Gene Medicine. 2005;7(8):1035-43.

42. Srichana T, Suedee R, Reanmongkol W. Cyclodextrin as a potential drug carrier in salbutamol dry powder aerosols: the in-vitro deposition and toxicity studies of the complexes. Respir Med. 2001 Jun;95(6):513-9.

43. Vozone CM, Marques HMC. Complexation of Budesonide in Cyclodextrins and Particle Aerodynamic Characterization of the Complex Solid Form for Dry Powder Inhalation. Journal of Inclusion Phenomena and Macrocyclic Chemistry. 2002;44(1):111-6.

44. Carpenter JF, Crowe JH. An infrared spectroscopic study of the interactions of carbohydrates with dried proteins. Biochemistry. 1989 May 2;28(9):3916-22.

45. Chang LL, Shepherd D, Sun J, Tang XC, Pikal MJ. Effect of sorbitol and residual moisture on the stability of lyophilized antibodies: Implications for the mechanism of protein stabilization in the solid state. J Pharm Sci. 2005 Jul;94(7):1445-55.

46. Branchu S, Forbes RT, York P, Petrén S, Nyqvist H, Camber O. Hydroxypropyl- $\beta$-cyclodextrin inhibits spray-drying-induced inactivation of $\beta$-galactosidase. Journal of Pharmaceutical Sciences. 1999 1999/09/01;88(9):905-11.

47. Tavornvipas S, Hirayama F, Takeda S, Arima H, Uekama K. Effects of cyclodextrins on chemically and thermally induced unfolding and aggregation of lysozyme and basic fibroblast growth factor. J Pharm Sci. 2006 Dec;95(12):2722-9. 
48. Loftsson T, Jarho P, Masson M, Järvinen T. Cyclodextrins in drug delivery. Expert opinion on drug delivery. 2005;2(2):335-51.

49. Otzen DE, Knudsen BR, Aachmann F, Larsen KL, Wimmer R. Structural basis for cyclodextrins' suppression of human growth hormone aggregation. Protein Sci. 2002 Jul;11(7):1779-87.

50. Chang LL, Shepherd D, Sun J, Ouellette D, Grant KL, Tang XC, et al. Mechanism of protein stabilization by sugars during freeze-drying and storage: Native structure preservation, specific interaction, and/or immobilization in a glassy matrix? Journal of Pharmaceutical Sciences. 2005;94(7):1427-44.

51. Allison SD, Chang B, Randolph TW, Carpenter JF. Hydrogen bonding between sugar and protein is responsible for inhibition of dehydration-induced protein unfolding. Archives of Biochemistry and Biophysics. 1999;365(2):289-98.

52. Schüle S, Frieß W, Bechtold-Peters K, Garidel P. Conformational analysis of protein secondary structure during spray-drying of antibody/mannitol formulations. European Journal of Pharmaceutics and Biopharmaceutics. [doi: 10.1016/j.ejpb.2006.08.014]. 2007;65(1):1-9.

53. Maury M, Murphy K, Kumar S, Mauerer A, Lee G. Spray-drying of proteins: effects of sorbitol and trehalose on aggregation and FT-IR amide I spectrum of an immunoglobulin G. Eur J Pharm Biopharm. 2005 Feb;59(2):251-61.

54. Tian F, Middaugh CR, Offerdahl T, Munson E, Sane S, Rytting JH. Spectroscopic evaluation of the stabilization of humanized monoclonal antibodies in amino acid formulations. Int J Pharm. 2007 Apr 20;335(1-2):20-31. 


\section{Legend}

Figure1. Effect of trehalose and BCD ratio on spray drying yield

Figure2. the scanning electron microscopy of microparticles containing of BCD (a), HPBCD (b), trehalose(c) with the ratio of $1: 1$ to antibody and optimum formulation (d).

Figure 3.Significant interactions HPBCD and trehaloseon particle size

Figure 4. The close relationship between particle size and span

Figure 5.The effect of HPBCD and Trehalose interaction on span

Figure 6. Effect of various parameters on particle fine particle fraction (FPF)

Figure 7. Effect of augmentation of HPBCD and trehalose in antibody stability by measuring the Amount (\%) of remained antibody monomer immediately after spray drying (A),1 monthstoring(B) and 3 month storing(C)

Figure 8.FTIRsecondary derivative spectra of antibody of spray dried pure antibody and antibody with HPBCD, BCD and Trehalosein the ratio of $1: 1$. The peack position in $1940 \mathrm{~cm}^{-1}$ is the main band which indicatedthe antibody beta sheet content.

Figure 9.The effect of trehalose and HPBCD ratios on preservation of antibody beta sheet content. 


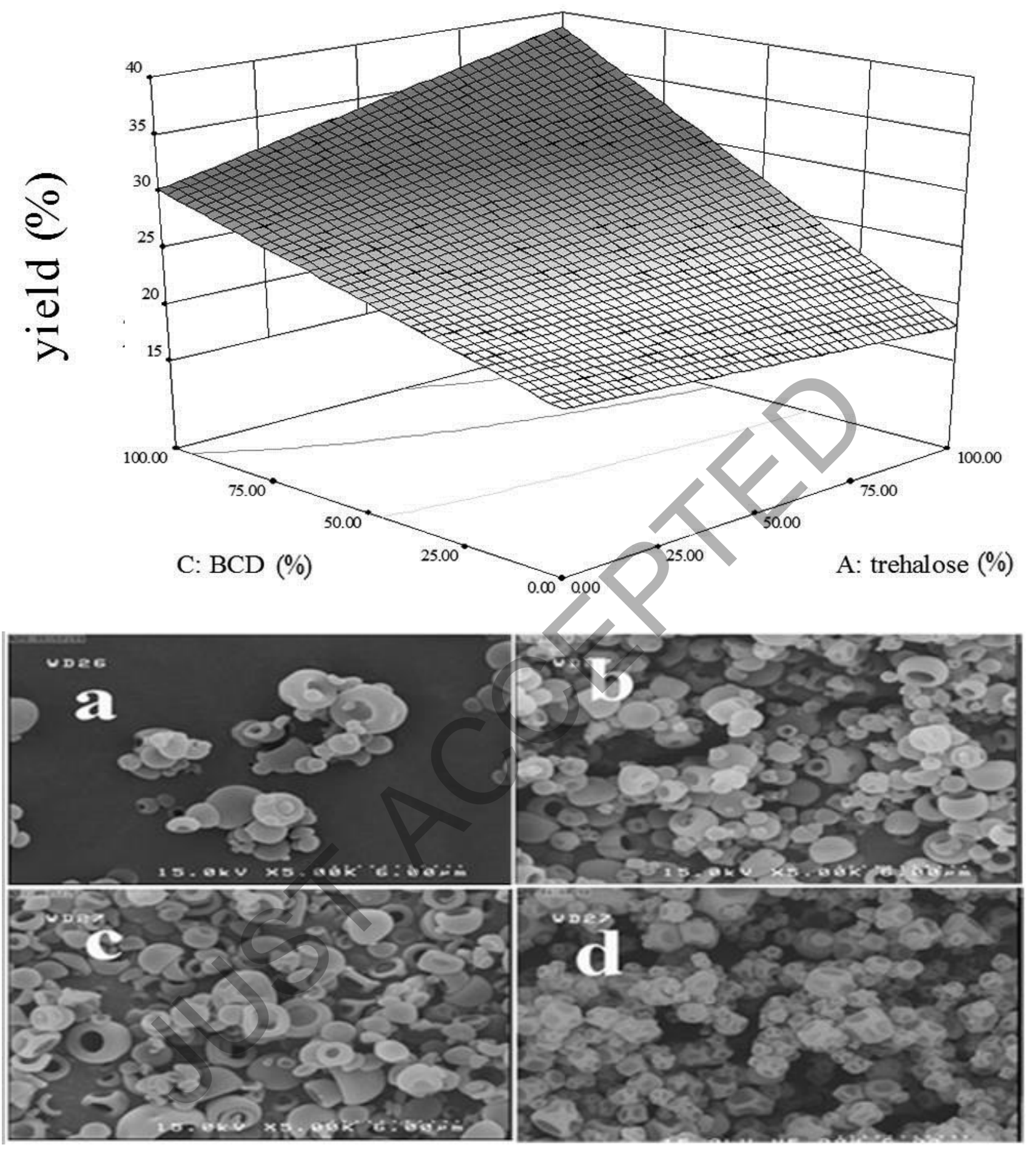



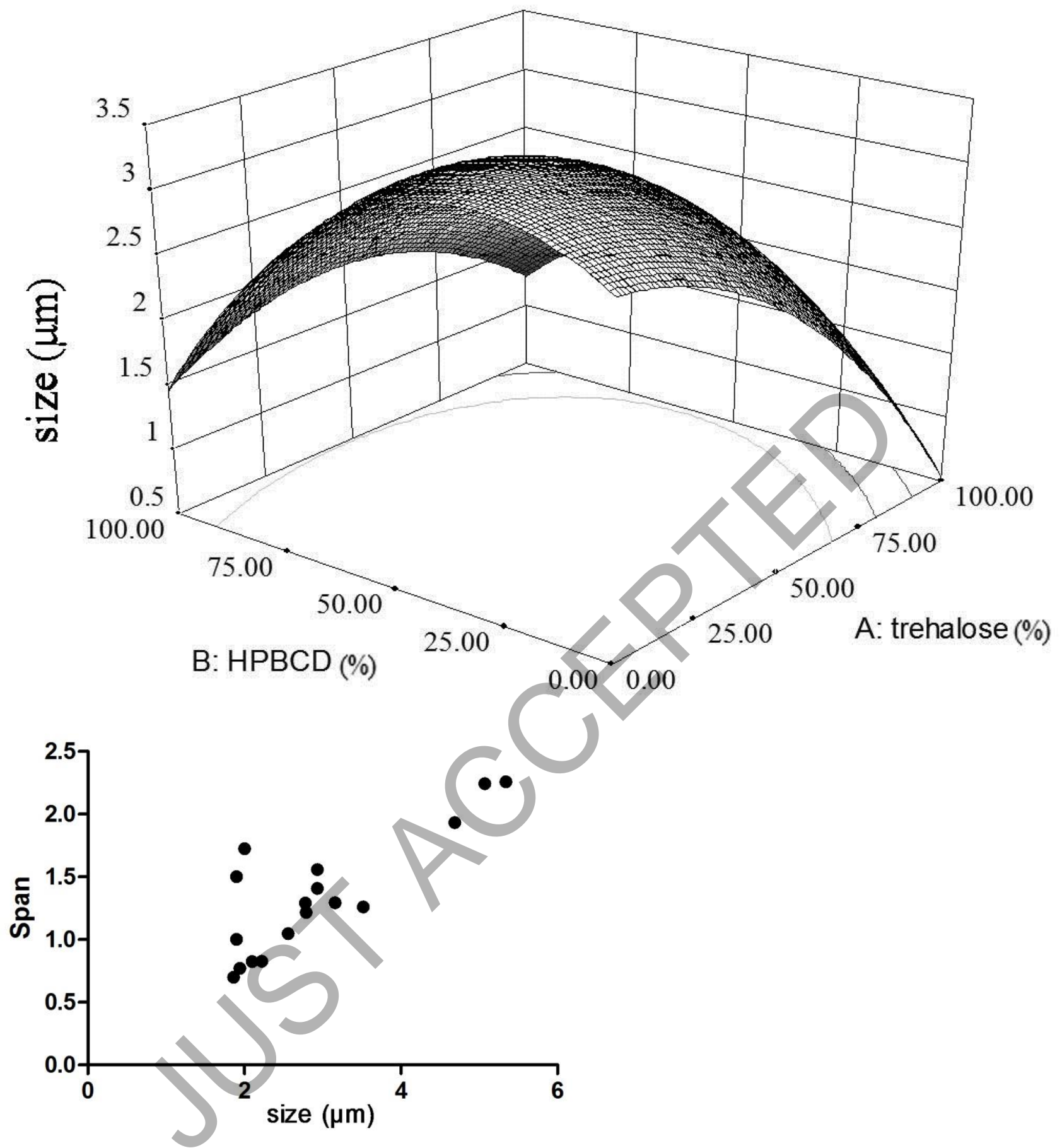

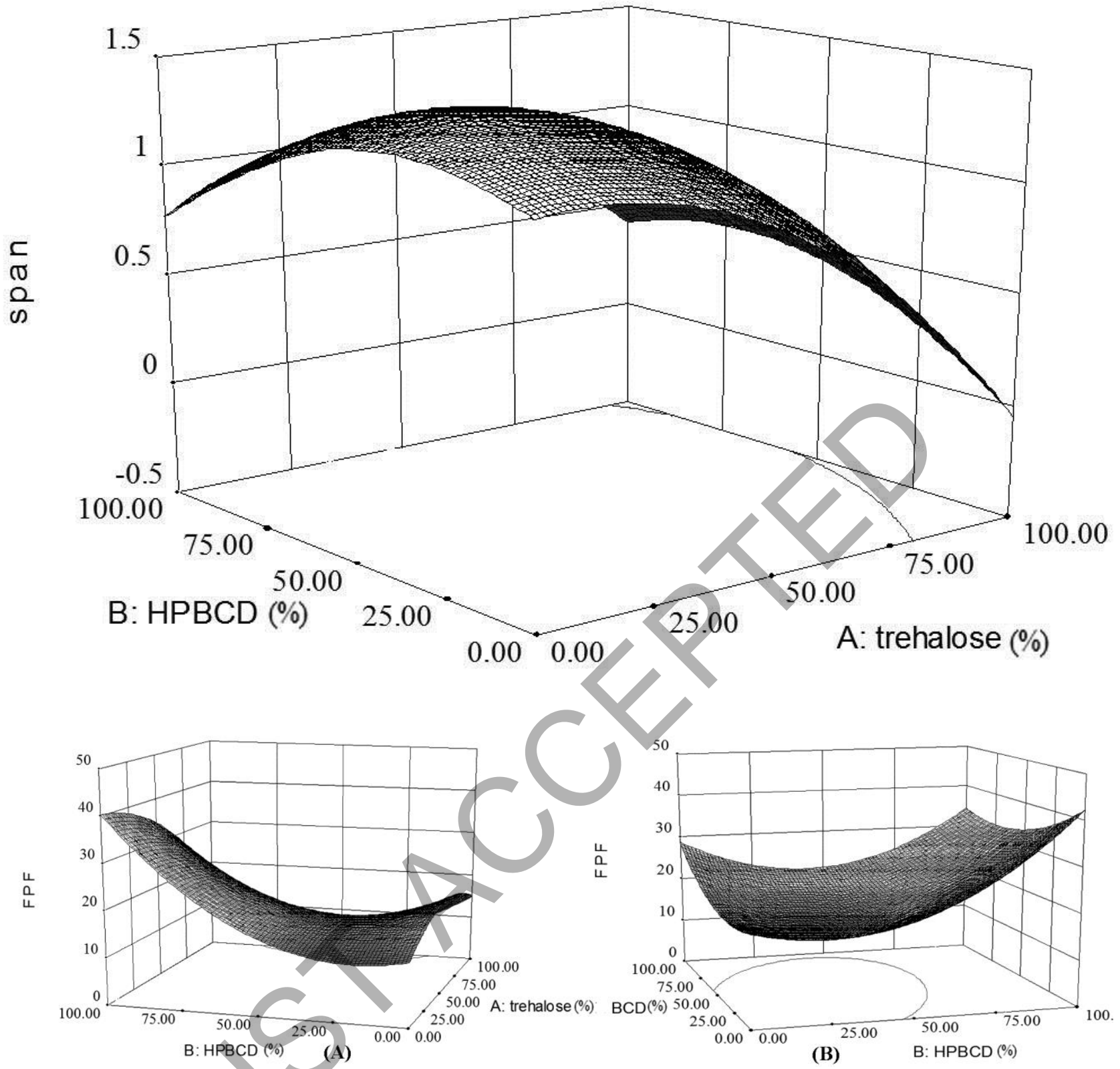

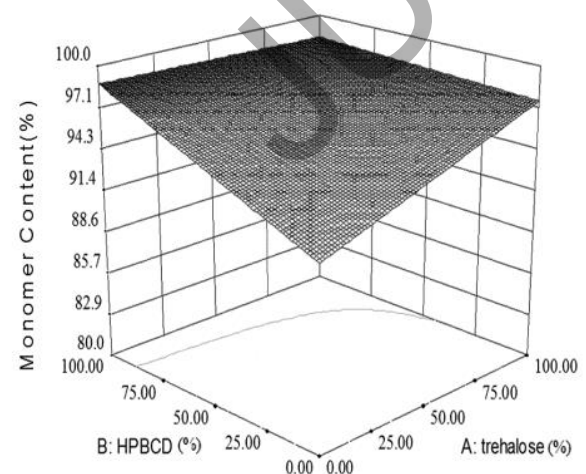

A

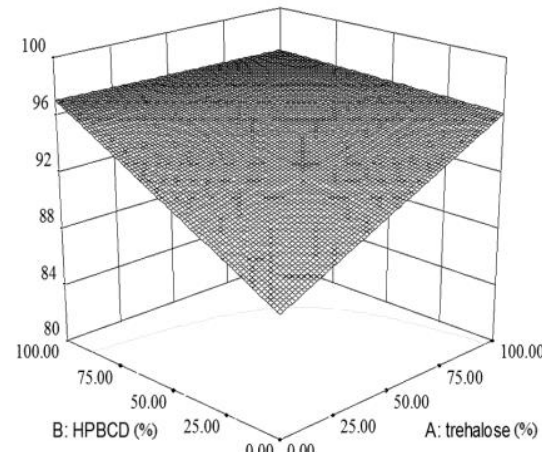

B

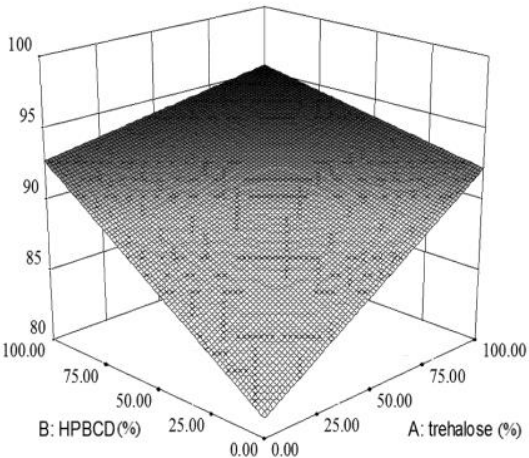

C 

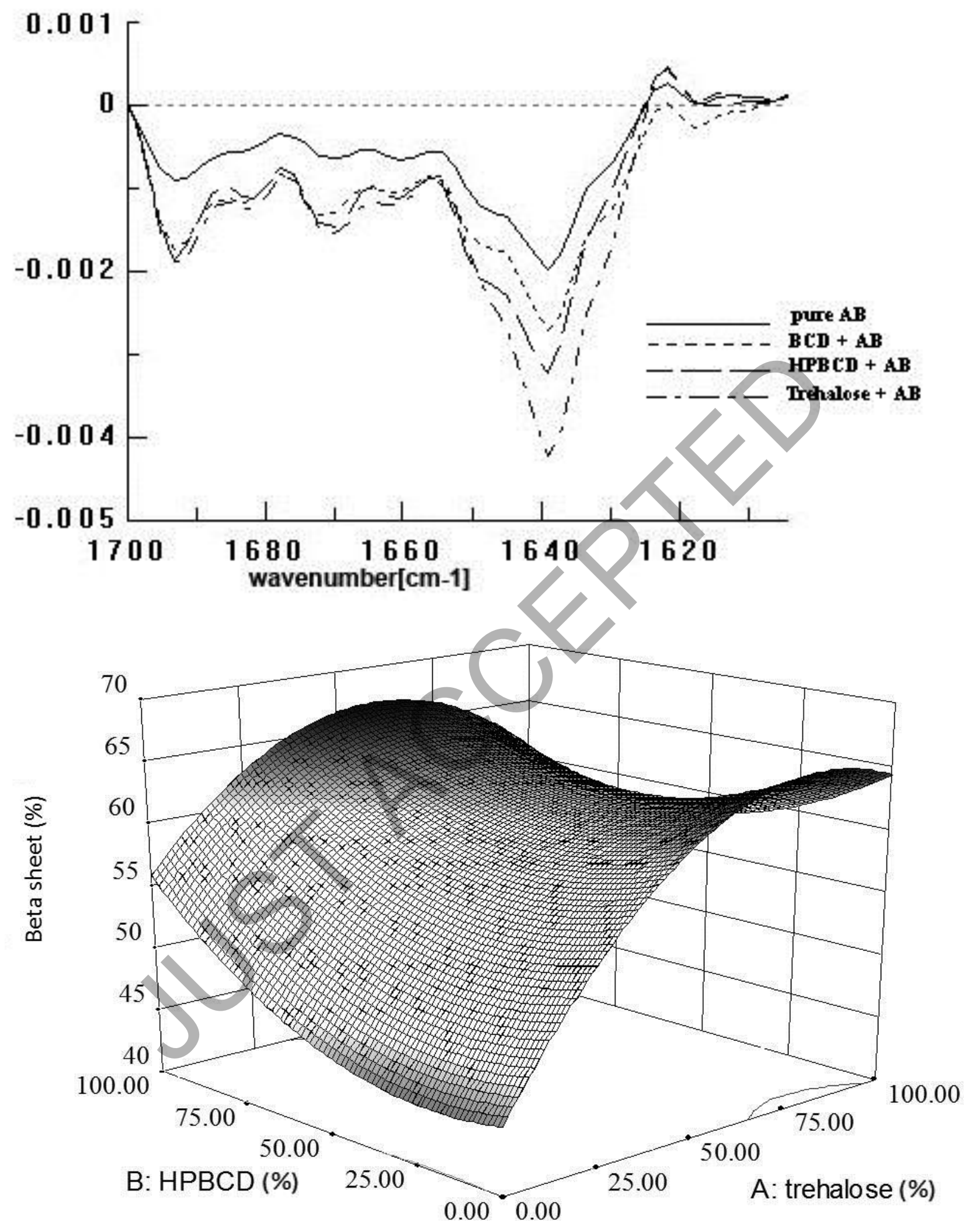
Table 1. D-Optimal design and the responses from the analyses

Monomer content

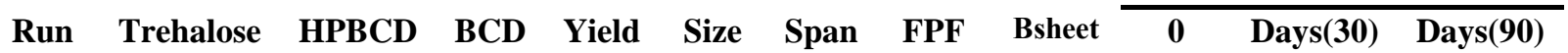

(A)

(B)

(C)

$(\%)$

(\%) (\%)

\begin{tabular}{cccccccccccc}
\hline F 1 & -1 & -1 & 1 & 33.6 & 5.34 & 2.26 & 29.84 & 47.02 & 93 & 91.5 & 89.56 \\
F 2 & 0 & 0 & 1 & 35.33 & 5.07 & 2.24 & 19.27 & 59.04 & 96 & 97.33 & 95.29 \\
F 3 & -1 & 1 & 1 & 32 & 3.16 & 1.29 & 41.62 & 55.7 & 99 & 96.73 & 95.13 \\
F 4 & 1 & 1 & 1 & 45.16 & 2.93 & 1.41 & 15.81 & 62.84 & 100 & 97.04 & 95.27 \\
F 5 & -1 & -1 & -1 & 15.67 & 2.93 & 1.56 & 7.85 & 41.1 & 87.11 & 82.11 & 69.72 \\
F 6 & 0.5 & -0.5 & 0 & 23.8 & 2.22 & 0.83 & 9.81 & 64.25 & 99.1 & 96.07 & 91.09 \\
F 7 & 0 & 1 & 0 & 27.17 & 1.9 & 1 & 35 & 63.47 & 97.2 & 96.77 & 92.53 \\
F 8 & 1 & -1 & 1 & 33 & 2.1 & 0.82 & 22 & 60.16 & 98 & 97.12 & 92 \\
F 9 & 1 & 1 & 1 & 41.87 & 2.77 & 1.29 & 16 & 62.05 & 99.5 & 97.54 & 95.99 \\
F 10 & -1 & 1 & -1 & 27.2 & 2 & 1.72 & 52.23 & 57.74 & 98.2 & 96.56 & 92.56 \\
F 11 & -1 & 1 & -1 & 20 & 1.9 & 1.5 & 41.53 & 56.92 & 99.13 & 94.13 & 87.9 \\
\hline F 12 & 1 & 0 & -1 & 15.6 & 1.86 & 0.7 & 15.31 & 59.18 & 98 & 95.17 & 92.47 \\
F 13 & -1 & 0 & 0 & 26.4 & 3.52 & 1.26 & 18.80 & 46.15 & 97.73 & 94.73 & 87.77 \\
\hline F 14 & 1 & 1 & -1 & 20.5 & 1.94 & 0.77 & 25 & 60.556 & 97 & 96.17 & 95.48 \\
F 15 & 1 & -1 & -1 & 18.6 & 1.2 & 0.55 & 17.44 & 66.32 & 95 & 92.43 & 90.29 \\
F 16 & -1 & -1 & 1 & 27.6 & 4.68 & 1.93 & 23 & 45.9 & 95.48 & 90.48 & 88.6 \\
\hline F 17 & 0 & -1 & -1 & 19.6 & 2.66 & 1.15 & 23.73 & 66.74 & 96.39 & 94.39 & 87.32 \\
F 18 & -1 & 1 & 1 & 28.33 & 2.79 & 1.21 & 45 & 56.74 & 99 & 99.9 & 96.2 \\
\hline
\end{tabular}


Table2. Fitted models and ANOVA analysis of various factors

\begin{tabular}{|c|c|c|c|c|c|c|c|c|}
\hline & $\begin{array}{l}\text { Yield } \\
(\%)\end{array}$ & $\begin{array}{c}\text { Particle } \\
\text { Size } \\
(\mu \mathrm{m})\end{array}$ & Span & $\begin{array}{l}\text { FPF } \\
(\%)\end{array}$ & $\begin{array}{c}\text { Monomer } \\
\text { Content } \\
\text { Day(0) }\end{array}$ & $\begin{array}{c}\text { Monomer } \\
\text { Content } \\
\text { Day(30) }\end{array}$ & $\begin{array}{c}\text { Monomer } \\
\text { Content } \\
\operatorname{Day}(90)\end{array}$ & $\begin{array}{c}\beta \text { sheet } \\
\text { content } \\
(\%)\end{array}$ \\
\hline Model & $<0.0001$ & $<0.0001$ & 0.006 & 0.0004 & 0.0035 & 0.0022 & 0.0003 & $<0.0001$ \\
\hline $\mathbf{A}$ & 0.1522 & $<0.0001$ & 0.0005 & 0.0019 & 0.036 & 0.0077 & 0.0008 & $<0.0001$ \\
\hline B & 0.0341 & 0.0466 & 0.770 & 0.0004 & 0.0048 & 0.0021 & 0.0005 & 0.0177 \\
\hline C & $<0.0001$ & $<0.0001$ & 0.0596 & 0.7861 & 0.0829 & 0.012 & 0.0017 & - \\
\hline $\mathbf{A}^{2}$ & - & 0.0431 & 0.1060 & 0.1147 & - & & - & 0.0003 \\
\hline $\mathbf{B}^{2}$ & - & 0.002 & 0.2234 & 0.009 & - & & - & 0.0209 \\
\hline $\mathbf{C}^{2}$ & - & 0.004 & 0.0185 & 0.1907 & - & & - & - \\
\hline $\mathbf{A B}$ & 0.3171 & 0.0003 & 0.0287 & 0.0012 & & 0.0082 & 0.0271 & 0.0005 \\
\hline $\mathbf{A C}$ & 0.0138 & - & - & 0.0711 & & 0.3241 & 0.0095 & - \\
\hline BC & - & - & - & 0.0108 & & 0.3141 & 0.0686 & - \\
\hline LoF & 0.6935 & 0.2298 & 0.0580 & 0.5928 & 0.0531 & 0.1662 & 0.1333 & 0.0048 \\
\hline
\end{tabular}

A: Trehalose, B: Hydroxypropyl beta cyclodextrin, C: Beta cyclodextrin, LoF: Lack of fit

Table 3. the value of optimized antibody formulation

\begin{tabular}{|c|c|c|c|c|c|c|c|c|}
\hline \multirow[t]{2}{*}{ Response } & \multirow{2}{*}{ Yield } & \multirow{2}{*}{$\begin{array}{c}\text { Particle Size } \\
(\mu \mathrm{m})\end{array}$} & \multirow[t]{2}{*}{ Span } & \multirow{2}{*}{$\begin{array}{l}\text { FPF } \\
(\%)\end{array}$} & \multirow{2}{*}{$\begin{array}{c}\text { Bsheet } \\
\text { content } \\
(\%)\end{array}$} & \multicolumn{3}{|c|}{ Remained Monomer } \\
\hline & & & & & & $\operatorname{Day}(0)$ & $\operatorname{Day}(30)$ & $\operatorname{Day}(90)$ \\
\hline predicted & 34.48 & 3.6 & 1.63 & 38.85 & 65.34 & 99.67 & 98.3 & 96.0 \\
\hline
\end{tabular}

